\title{
Penerapan Model Pembelajaran Discovery Learning Untuk Meningkatkan Hasil Belajar IPA Kelas V SDN 124 Batuasang Kecamatan Herlang Kabupaten Bulukumba
}

\author{
Arnita M. Basri ${ }^{1}$, Rohana ${ }^{2}$, Hamzah Pagarra ${ }^{3}$ \\ ${ }^{123}$ Program Studi PGSD FIP UNM \\ ${ }^{1}$ arnitambasri@yahoo.com \\ ${ }^{2}$ rohana@unm.ac.id \\ 3hamzah.pagarra@unm.ac.id
}

\begin{abstract}
ABSTRAK
Penelitian ini adalah penelitian tindakan kelas (Classroom Action Research) yang bertujuan untuk meningkatkan hasil belajar IPA dengan penerapan model pembelajaran discovery learning. Pendekatan yang digunakan dalam penelitian ini adalah kualitatif dengan jenis penelitian adalah Penelitian Tindakan Kelas (PTK) yang berdaur ulang/ siklus yang meliputi perencanaa, pelaksanaan, observasi, dan refleksi. Teknik pengumpulan data yang digunakan adalah observasi, tes, dan dokumentasi. Analisis data yang digunakan adalah kualitatif. Hasil penelitian menunjukkan bahwa ada peningkatan dalam pembelajaran baik pada aktivitas guru dan siswa maupun hasil belajar siswa. Dari penelitian ini dapat disimpulkan bahwa aktivitas mengajar guru dan aktivitas belajar siswa terjadi peningkatan, hasil belajar siswa pada siklus I belum berada pada kategori cukup, pada siklus II hasil belajar siswa sudah meningkat berada pada kategori baik dan Penerapan model Pembelajaran discovery learning dalam mata pelajaran IPA dapat meningkatkan hasil belajar siswa kelas V SDN 124 Batuasang Kecamatan Herlang Kabupaten Bulukumba.
\end{abstract}

Kata kunci: Model Discovery Learning, Hasil Belajar.

\section{PENDAHULUAN}

Pendidikan merupakan pilar utama terhadap perkembangan suatu bangsa. Pendidikan merupakan sarana penting untuk meningkatan kualitas sumber daya manusia secara menyeluruh dalam menjamin keberlangsungan pembangunan suatu bangsa. Pendidikan diharapkan mampu menciptakan manusia-manusia unggul melalui proses memanusiakan manusia sebagaimana hakekat pendidikan. Umumnya di sekolah dasar, guru kelas mengajarkan lima mata pelajaran salah satunya yaitu Ilmu Pengetahuan Alam (IPA). BSNP mengemukakan bahwa tujuan pembelajaran IPA di sekolah dasar yaitu: 1 . Memperoleh keyakinan terhadap kebesaran Tuhan Yang Maha Esa berdasarkan keberadaan, keindahan dan keteraturan alam ciptaan-Nya; 2. Mengembangkan pengetahuan dan pemahaman konsep-konsep IPA yang bermanfaat dan dapat diterapkan dalam kehidupan sehari-hari; 3. Mengembangkan rasa ingin tahu, sikap positif dan kesadaran tentang adanya hubungan yang saling mempengaruhi antara IPA, lingkungan, teknologi dan masyarakat; 4. Mengembangkan keterampilan proses untuk menyelidiki alam sekitar, memecahkan masalah dan membuat keputusan; 5. Meningkatkan kesadaran untuk berperan serta dalam memelihara, menjaga dan melestarikan lingkungan alam; 6 . Meningkatkan kesadaran untuk menghargai alam dan segala keteraturannya sebagai salah satu ciptaan Tuhan; 7. Memperoleh bekal pengetahuan, konsep dan keterampilan IPA sebagai dasar untuk melanjutkan pendidikan ke SMP/MTs. (Susanto, 2013: 171).

Mengingat pembelajaran IPA di sekolah dasar begitu penting maka seorang guru perlu merancang, memahami, dan melaksanakan pembelajaran IPA dengan sebaik mungkin sehingga konsep-konsep IPA yang diajarkan dapat dipahami siswa dengan baik, sehingga memungkinkan siswa terlibat secara langsung dan aktif dalam proses pembelajaran. Umumnya, pengajaran IPA dilakukan dengan cara menceramahkan konsep-konsep, prinsip dan hukum-hukum dalam bentuk yang sudah jadi kepada siswa, sehingga pembelajaran menjadi monoton dan siswa tidak berpartisipasi aktif dalam pembelajaran. Hal ini tidak sesuai dengan hakikat pembelajaran IPA bahwa pembelajaran IPA berdasarkan 
pada prinsip-prinsip, proses yang dapat menumbuhkan sikap ilmiah siswa terhadap konsep-konsep IPA. Oleh karena itu, pembelajaran IPA dilakukan bukan dengan hafalan tetapi melalui diskusi, pengamatan dan penyelidikan sederhana dengan begitu proses pembelajaran menjadi aktif dan tidak monoton sehingga dapat membawa pengaruh yang sangat berarti bagi peningkatan pemahaman siswa terhadap materi yang diajarkan.

Berdasarkan hasil observasi awal di kelas V SDN 124 Batuasang Kecamatan Herlang Kabupaten Bulukumba pada proses pembelajaran diperoleh informasi yaitu: factor guru dan factor siswa. Faktor guru yakni: 1) Guru kurang mengaitkan materi pembelajaran dengan kehidupan nyata siswa, 2) Guru kurang meningkatkan kemampuan siswa dalam memecahkan masalah, 3) Guru kurang mendorong siswa untuk berpikir dan bekerja atas inisiatif sendiri, 4) Guru kurang melatih kemampuan siswa untuk menemukan sendiri, dan 5) guru kurang memberi kesempatan bagi siswa untuk berpartisipasi aktif. Sedangkan faktor siswa, yaitu: 1) Siswa kurang berpartisipasi aktif dalam pembelajaran, 2) siswa kurang konsentrasi pada saat pembelajaran berlangsung, 3) siswa kurang mampu memecahkan masalah, 4) siswa kurang terampil dalam menemukan sendiri, dan 5) siswa kurang mampu mengaitkan materi pembelajaran dengan kehidupan nyata.

Berdasarkan permasalahan tersebut maka salah satu model yang dapat digunakan untuk menciptakan suasana belajar yang aktif, dapat memecahkan masalah dalam proses pembelajaran yaitu model pembelajaran discovery learning. Model pembelajaran discovery learning adalah model untuk mengembangkan cara belajar aktif dengan menemukan sendiri, menyeledki sendiri. Model pembelajaran discovery learning memiliki kelebihan yaitu siswa akan mengerti konsep dan ide- ide yang lebih baik, mendorong siswa mendorong berpikir dan bekerja atas inisiatif sesndiri, siswa bealajar dengan memanfaatkan berbagai jenis sumber belajar. Penelitian sebelumnya yang dilakukan oleh Dina Lidya Noprida (2016) mengemukakan bahwa penerapan model discovery learning dalam mata pelajaran IPA dapat meningkatkan hasil belajar siswa.

Berdasarkan latar belakang tersebut, maka peneliti merumuskan masalah yaitu: Bagaimanakah Penerapan Model Pembelajaran Discovery Learning untuk meningkatkan hasil belajar siswa pada mata pelajaran IPA kelas V
SDN 124 Batuasang Kecamatan Herlang Kabupaten Bulukumba? Tujuan penelitian ini adalah untuk mendeskripsikan penerapan model pembelajaran discovery learning untuk meningkatkan hasil belajar siswa pada mata pelajaran IPA kelas V SDN 124 Batuasang Kecamatan Herlang Kabupaten Bulukumba.

METODE PENELITIAN Pendekatan dalam penelitian ini menggunakan pendekatan kualitatif. Tujuan dari pendekatan ini untuk mencari, menemukan dan membuktikan pengetahuan yang diperoleh khususnya dalam penerapan model pembelajaran discovery learning untuk meningkatkan hasil belajar siswa pada mata pelajaran IPA kelas V SDN 124 Batuasang Kecamatan Herlang Kabupaten Bulukumba.

Sugiyono (2016: 15) mengemukakan bahwa: Metode penelitian kualitatif adalah metode penelitian yang berlandaskan pada filsafat postpositivisme, digunakan untuk meneliti pada kondisi objek yang alamiah, (sebagai lawannya adalah eksperimen) di mana peneliti adalah sebagai instrument kunci, pengambilan sampel sumber data dilakukan secara purposive dan snowbaal, teknik pengumpulan data dengan triangulasi (gabungan), analisis data bersifat induktif / kualitatif, dan hasil penelitian kualitatif lebih menekankan makna dari pada generalisasi.

Jenis penelitian ini adalah Penelitian Tindakan Kelas (Clasroom Action Research). Sanjaya (2010: 26) Menyatakan PTK dapat diartikan sebagai proses pengkajian masalah pembelajaran di dalam kelas melalui refleksi diri dalam upaya untuk memecahkan maslah tersebut dengan cara melakukan berbagai tindakan yang terencana dalam situasi nyata serta menganalisis setiap pengaruh dan perlakuan tersebut.

Fokus penelitian ini adalah penerapan model pembelajaran discovery learning dalam meingkatkan hasil belajar siswa pada mata pelajaran IPA kelas V SDN 124 Batuasang Kecamatan Herlang Kabupaten Bulukumba. Adapun yang dimaksud dari fokus penelitian tersebut yaitu:

Mekanisme pelaksanaan tindakan penelitian ini mengikuti model Arikunto (2017), karena apabila guru tidak puas dengan hasil pembelajarannya, dan ingin mengubah pembelajaran itu dengan model yang sifatnya baru sehingga ia mencobanya. Mencoba tidak hanya sekali saja, tetapi berulang- ulang sehingga penelitiannya itu disebut penelitian tindakan. Rancangan tindakan yang digunakan 
dalam pelaksanaan penelitian yaitu dengan empat langkah utama: perencanaan, pelaksanaan, pengamatan, dan refleksi.

Untuk memperoleh data yang diperlukan dalam penelitian ini, maka digunakan teknik dan prosedur pengumpulan data. Teknik dan prosedur pengumpulan data pada penelitian ini adalah: Observasi, Tes, Dokumentasi,

Teknik yang dilakukan adalah teknik analisis data kualitatif yang berdasar pada hasil observasi dan tes belajar siswa kelas V SDN 124 Batuasang Kecamatan Herlang Kabupaten Bulukumba melalui penerapan model pembelajaran dengan berkerja sama (berpasangan). Data proses analisis dengan menggunakan teknik analisis data kualitatif terdiri dari 3 tahap kegiatan yaitu:Mereduksi data, Menyajikan data, menarik kesimpulan.

Indikator keberhasilan dalam penelitian tindakan kelas ini meliputi indikator proses dan hasil dalam penggunaan model pembelajaran discovery learning untuk meningkatkan hasil belajar siswa.

Indikator keberhasilan dari segi proses pembelajaran, apabila terjadi peningkatan pada kegiatan pembelajaran baik guru dan siswa yang diperoleh melalui lembar observasi. Keberhasilan proses pembelajaran dapat terlihat dari terlaksanannya semua langkahlangkah pembelajaran dengan baik.

Indikator hasil dapat dilihat dari meningkatnya hasil jika terdapat $80 \%$ siswa memperoleh nilai minimum 75 pada mata pelajaran IPA setelah diterapkan model pembelajaran discovery learning maka pembelajaran dianggap tuntas secara klasikal.

\section{HASIL \& PEMBAHASAN}

\section{A. Hasil Penelitian}

\section{Paparan Data Siklus I}

Dalam bagian ini dipaparkan data dan temuan hasil tindakan pembelajaran materi gaya magnet dengan menggunakan model pembelajaran Discovery Learning. Data tindakan, temuan dan refleksi diperoleh melalui observasi. Data setiap siklus dipaparkan secara terpisah. Hal ini bertujuan untuk melihat persamaan, perbedaan, perubahan dan perkembangan alur setiap siklus. Materi pelajaran gaya magnet dengan menggunakan model Discovery Learning mencakup (1) perencanaan pembelajaran, (2) pelaksanaan pembelajaran, (3) observasi, dan (4) refleksi tindakan.

\section{a. Perencanaan Siklus I}

Sebelum melaksanakan tindakan, peneliti dan guru kelas $\mathrm{V}$ secara kolaboratif menyusun pelaksanaan pembelajaran (RPP), lembar kerja siswa (LKS), tes siklus I, dan format observasi guru dan siswa. Perencanaan tersebut disusun dan dikembangkan berdasarkan program semester II dan mengacu pada langkah- langkah model pembelajaran discovery learning. Perencanaan tindakan terdiri atas (1) menentukan materi pembelajaran, (2) menentukan tujuan pembelajaran, (3) menentukan langkahlangkah pembelajaran, (4) memilih bahan/ materi pelajaran, (5) menyusun tes hasil belajar. Perencanaan pembelajaran ini mengambil materi gaya magnet yang diambil dari buku paket IPA untuk SD untuk sekolah dasar kelas $\mathrm{V}$ penerbit erlangga.

\section{b. Pelaksanaan Siklus I}

Pelaksanaan tindakan siklus I dilaksanakan dalam 2 tindakan ( 2 x pertemuan) dengan alokasi wartu 3 x 35 menit tiap pertemuan yang dilaksanakan pada rabu 25 April 2018 dan sabtu 28 april 2018 sesuai dengan rencana yang telah disusun pada RPP siklus I pertemuan I dan RPP siklus I pertemuan II. Materi siklus I yaitu hubungan antar gaya, gerak dan energi serta fungsinya.

\section{1) Pertemuan I siklus I}

Pertemuan pertama dilaksanakan pada hari rabu 25 april 2018 dengan materi hubungan antar gaya, gerak dan energi serta funginya dengan indikator gaya magnet terdiri dari tiga kegiatan yakni kegiatan awal, kegiatan inti, dan kegiatan penutup. Alokasi waktu pada pertemuan ini adalah 3 x 35 menit, proses pembelajaran dilaksanakan pada pukul 09.30- 10.45 WITA

a) Kegiatan Awal

Pada kegiatan awal berlangsung selama \pm 15 menit yaitu guru mengucapkan salam dan siswa menjawab salam, kemudian guru mengecek kesiapan belajar siswa, dan melakukan doa bersama. Selanjutnya guru mengecek kehadiran siswa yang terdiri dari 14 orang siswa yaitu 10 laki- laki dan 4 perempuan, setelah mengecek kehadiran diketahuai bahwa siswa yang hadir pada pertemuan pertama siklus I sebanyak 14 siswa. Sebelum guru melakukan apersepsi terlebih dahulu guru memperkenalkan diri karena pada pertemuan ini merupakan pertemuan pertama dan sebagaian besar siswa belum mengenal dengan gurunya. Setelah melakukan apersepsi, maka guru menyampaikan tujuan 
pembelajaran dan langkah- langkah pembelajaran.

\section{b) Kegiatan Inti}

Pada kegiatan ini berlangsung selama \pm 80 menit. Dengan mengawali kegiatan inti, guru membentuk siswa dalam kelompok dikarenakan langkah- langkah model pembelajaran discovery learning ada kegiatan berdiskusi kelompok. Untuk memudahkan guru dalam membimbing setiap kelompok maka guru membagi siswa kedalam 4 kelompok, dua kelompok beranggotankan 2 orang dan dua kelompok beranggotakan 3 orang hal ini dikarenakan jumlah siswa kelas $\mathrm{V}$ memiliki 14 orang siswa. Setalah semua siswa berada pada kelompok masing- masing, maka guru menjelaskan langkah- langkah yang akan dilakukan dalam kegiatan percobaan tentang gaya magnet.

a. Melakukan eksplorasi, percobaan

Guru membagikan lembar kerja siswa (LKS), pada LKS ini memuat langkahlangkah kegiatan yang akan dilakukan siswa yaitu percobaan tentang gaya magnet, adapun langkah- langkah kegiatan yaitu (1) meminta siswa mendekatkan magnet dengan benda yang telah disiapkan, (2) meminta siswa mengamati benda tersebut, (3) siswa diminta mengelompokkan benda yang ditarik dan tidak ditarik oleh magnet.

b. Mencatat hasil

Guru meminta siswa untuk mencatat seluruh data hasil percobaan yang sudah dilakukan dan berdiskusi dengan teman kelompoknya untuk menjawab pertanyaan yang ada pada LKS dimana pertanyaan disesuaikan dengan percobaan yang telah dilakukan

c. Mendiskusikan

Siswa diminta untuk mendiskusikan hasil kegiatan yang telah dilakukan secara berkelompok.

d. Menyusun laporan kegiatan

Siswa diminta untuk membuat laporan secara berkelompok tentang hasil kegiatan yang telah dilakukan kemudian dipresentasikan oleh ketua disetiap kelompok. e. Presentasi

Ketua kelompok mempresentasikan hasil kerja kelompok dan membacakan di depan kelas dan kelompok lain menanggapi hasil kerja kelompok yang dibacakan. Dalam pembacaan hasil diskusi, dapat dilihat bahwa beberapa siswa mempunyai keberanian dalam membacakan hasil diskusi tetapi untuk menanggapi hasil temuan kelompok lain siswa merasa kesulitan dikarenakan tidak dibiasakan siswa untuk betanya, siswa juga masih kurang memahami dalam menyusun pertanyaan.

f. Penjelasan Materi

Guru memberikan penguatan materi atau menjelaskan lebih lanjut yang sudah dipelajari tentang gaya magnet.

c) Kegiatan Penutup

Pada kegiatan penutup ini berlangsung \pm 10 menit, yang pertama dilakukan guru yaitu guru menyimpulkan materi pembelajaran, kemudian memberikan motivasi yang membangun kepada siswa dan menyampaikan pesan- pesan moral kepada siswa, seperti jangan lupa mengulangi pelajarannya di rumah, rajin membantu orang tua dan melaksanakan sholat lima waktu. Kemudian yang terakhir guru mengucapkan salam penutup dan siswa menjawab salam tersebut.

\section{2) Pertemuan II Siklus I}

Proses pembelajaran materi hubungan antar gaya, gerak dan energi serta fungsinya pada pertemuan ini dengan indikator gaya gravitasi dan gaya gesek terdiri dari 3 kegiatan yakni kegiatan awal, kegiatan inti, dan kegiatan penutup. Alokasi waktu pada pertemuan ini 3 x 35 menit, proses pembelajaran dilaksanakan pada pukul 09.3010.54 WITA

a) Kegiatan Awal

Pada kegiatan awal ini berlangsung selama \pm 15 menit yaitu guru mengucapkan salam kemudian siswa menjawab salam dengan bersamaan, selanjutnya guru mengecek kesiapan belajar siswa, dan melanjutkan doa bersama. Selanjutnya guru mengecek kehadiran siswa yang terdiri dari 14 orang yaitu 10 orang siswa laki- laki dan 4 orang siswa perempuan, setelah mengecek kehadiran diketahuai bahwa siswa hadir semua pada pertemuan ini. Kemudian guru melakukan apersepsi dengan cara bertanya tentang hal- hal yang berkaitan materi pelajaran yang akan dipelajari. Setelah melakukan apersepsi, maka guru menyampaikan tujuan pembelajaran dan langkah- langkah pembelajaran.

b) Kegiatan Inti

Pada Kegiatan ini berlangsung selama $\pm \quad 70$ menit. Pelaksanaan kegiatan pembelajaran materi gaya gravitasi dan gaya gesek dengan menggunakan model discovery learning. Materi yang diajarkan pada pertemuan kedua ini yaitu gaya gravitasi dan gaya gesek melaului percobaan.

a Melakukan eksplorasi, percobaan

Guru membagikan Lembar kerja siswa

(LKS) kepada setiap kelompok untuk 
melakukan percobaan pertama tentang gaya gravitasi dan percobaan kedua gaya gesek. Kegiatan yang dilakukan siswa berdasarkan langkah- langkah yang ada pada LKS yaitu (1) meminta siswa letakkan benda yang disediakan ditepi meja, (2) meminta siswa menjatuhkan satu persatu benda tersebut dan mengamati apa yang terjadi. Pada percobaan gaya gesek dilakukan dengan langkah (1) meminta siswa meletakkan kotak korek api diatas ujung buku yang dimiringkan dengan kemiringan yang tetap, (2) mengatur kemiringan buku dengan menumpukkan sejumlah buku hingga kotak kerek api meluncur kebawah, (3) melakukan percobaan yang sama dengan melapisi buku dengan kain kasar pada kemiringan yang sama. $\mathrm{b}$ Mencatat hasil

Dalam melakukan kegiatan tentang gaya gravitasi dan gaya gesek, guru meminta siswa untuk mencatat seluruh data hasil kegiatan yang dilakukan.

c Mendiskusikan

Siswa secara berkelompok diminta untuk mendiskusikan hasil kegiatan yang telah dilakukan berdasarkan petunjuk yang ada pada LKS.

d Menyusun Laporan Kegiatan

Setelah semua kelompok mendiskusikan hasil kegiatan maka siswa diminta secara berkelompok menysun laporan hasil kegiatan.

e Presentase

Setelah siswa selasai menulis laporan kegiatan, maka maka guru memberikan kesempatan kepada setiap ketua kelompok untuk membacakan hasil diskusi dan kelompok lain diminta untuk menanggapi.

f Penjelasan Materi

Guru memberikan penguatan materi atau menjelaskan lebih lanjut yang sudah dipelajari tentang gaya gravitasi dan gaya gesek.

c) Kegiatan Penutup

Pada kegiatan ini berlangsung selama \pm 20 menit yaitu guru membimbing siswa menyimpulkan materi pelajaran, kemudian guru memberikan tes siklus I kepada masingmasing siswa, selanjutnya memberikan motivasi yang membangun kepada siswa dan menyampaikan pesan- pesan moral, seperti agar siswa selalu mengulangi pelajaran di rumah, rajin membantu orang tua dan harus melaksanakan shalat lima waktu. Kemudian guru mengucapkan salam penutup untuk mengakhiri pembelajaran pertemuan II siklus I dan siswa menjawab salam tersebut.
Setelah pelaksanaan pertemuan II siklus I, peneliti bertindak sebagai guru memeriksa tes siklus I siswa. Berdasarkan hasil pemeriksaan tes siklus I tersebut, ternyata masih siswa belum mampu menjawab semua soal dengan benar. Hal ini terbukti dari hasil tes siklus I dengan nilai rata- rata yang di peroleh siswa mencapai $68.57 \%$ (lampiran 18 halaman 101).

\section{c. Hasil Observasi Siklus I}

Pelaksanaan kegiatan pembelajaran dilakukan oleh peneliti dan diamati langsung oleh guru kelas V SDN 124 Batuasang Kecamatan Herlang Kabupaten Bulukumba, dan hasil observasi tersebut belum menunjukkan hasil yang maksimal. Adapun aspek yang diamati oleh pengamat (guru kelas V) yaitu aspek guru dan aspek siswa sebagai berikut:

\section{1) Pertemuan I Siklus I}

a) Aspek Guru

Kegiatan inti diawali dengan guru meminta siswa melakukan kegiatan eksplorasi, pencarian, dan penelusuran untuk mendapatkan informasi dilakukan dengan kategori baik (B), karena guru memberikan arahan dan menjelaskan kegiatan eksplorasi apa yang akan dilakukan, kemudian pada langkah kedua guru meminta siswa mencatat seluruh data hasil percobaan dilakukan dengan kategori kurang (K) karena guru kurang membimbing siswa dalam mencatat seluruh data hasil percobaan, kemudian pada langkah ketiga guru meminta siswa mendiskusikan hasil temuan dan memaknai data hasil percobaan secara berkelompok pada langkah ini dilakukan dengan kategori baik (C) karena guru kurang mengawasi jalannya diskusi kelompok sehingga diskusi kurang maksimal, selanjutnya pada langkah keempat yaitu guru meminta siswa secara kolaboratif menyusun laporan kegiatan tentang percobaan yang telah dilakukan pada langkah ini dilakukan dengan kategori cukup (C) karena guru hanya membimbing beberapa kelompok saja dalam menyusun laporan kegiatan. Langkah selanjutnya yaitu guru meminta perwakilan kelompok menyajikan hasil temuan dan di tanggapi oleh kelompok lain, pada langkah pembelajaran ini dilakukan dengan kategori cukup (C) karena guru meminta perwakilan kelompok untuk mempresentasikan hasil diskusi dan hanya beberapa kelompok menanggapi. Selanjutnya Guru memberikan penguatan materi atau memberikan pelajaran dilakukan dengan kategori baik (B) karena guru menyampaikan materi dengan baik dan 
jelas. Dari enam langkah pembelajaran model discovery learning pada aspek guru, dikategorikan cukup $72 \%$.

b) Aspek Siswa

Kegiatan inti diawali dengan siswa melakukan kegiatan ekplorasi, pencarian, penelusuran untuk mendapatkan informasi dilakukan dengan kategori baik ((B) karena siswa terlihat melakukan kegiatan ekplorasi, pencarian untuk mendapatkan informasi, selanjutnya siswa mencatat seluruh kegiatan yang dilakukan pada langkah ini dilakukan dengan kategori cukup (C) karena sebagian siswa hanya ribut dan tidak mencatat data hasil temuan. Selanjutnya pada langkah ketiga yaitu siswa berkelompok mendiskusikan hasil temuan dan memaknai data hasil temuan, pada langkah ini dilakukan dengan kategori cukup (C) karena sebagian besar siswa tidak terlihat berdiskusi dengan teman kelompoknya, langkah keempat yaitu siswa secara kolaboratif menyusun laoparan kegiatan, pada langkah ini dilakukan dengan kategori cukup (K) karena hanya ketua kelompok yang terlihat menyusun laporan hasil kegiatan. Langkah kelima yaitu perwakilan kelompok menyajikan hasil temuan dan ditanggapi kelompok lain, pada langkah pembelajaran ini dilakukan dengan kategori kurang (K) karena siswa kurang menanggapi perwakilan kelompok yang membacakan hasil diskusinya. Selanjutnya siswa mendengarkan penguatan materi dari guru dilakukan dengan kategori baik (B) karena siswa menyimak dengan baik apa yang disampaikan guru. Dari enam langkah pembelajaran model discovery learning pada aspek siswa, dikategorikan cukup $66 \%$.

\section{2) Pertemuan II Siklus I}

a) Aspek Guru

Selanjutnya kegiatan inti diawali dengan guru meminta siswa melakukan kegiatan eksplorasi, pencarian, dan penelusuran untuk mendapatkan informasi hal ini dilakukan dengan kategori baik (B) karena guru memberikan arahan dan menjelaskan kegiatan eksplorasi apa yang akan dilakukan, kemudian pada langkah kedua guru meminta siswa mencatat seluruh data hasil percobaan dilakukan dengan kategori cukup (C) karena guru kurang membimbing siswa dalam mencatat seluruh data hasil percobaan, kemudian pada langkah ketiga guru meminta siswa mendiskusikan hasil temuan dan memaknai data hasil percobaan secara berkelompok pada langkah ini dilakukan dengan kategori baik (C) karena guru kurang mengawasi jalannya diskusi kelompok sehingga diskusi kurang maksimal, selanjutnya pada langkah keempat yaitu guru meminta siswa secara kolaboratif menyusun laporan kegiatan tentang percobaan yang telah dilakukan pada langkah ini dilakukan dengan kategori cukup (C) karena guru kurang terlihat membimbing dalam menyusun laporan hasil kegiatan. Langkah selanjutnya yaitu guru meminta perwakilan kelompok menyajikan hasil temuan dan di tanggapi oleh kelompok lain, pada langkah pembelajaran ini dilakukan dengan kategori cukup (C) karena guru hanya meminta beberapa kelompok untuk menanggapi kelompok yang tampil. Selanjutnya Guru memberikan penguatan materi atau memberikan pelajaran dilakukan dengan kategori baik (B) karena guru menyampaikan materi dengan baik dan jelas. Dari enam langkah pembelajaran model discovery learning pada aspek guru, dikategorikan cukup $77 \%$.

b) Aspek Siswa

Kegiatan inti diawali dengan siswa melakukan kegiatan ekplorasi, pencarian, penelusuran untuk mendapatkan informasi dilakukan dengan kategori baik (B) karena siswa terlihat melakukan kegiatan ekplorasi, pencarian untuk mendapatkan informasi, selanjutnya siswa mencatat seluruh kegiatan yang dilakukan pada langkah ini dilakukan dengan kategori cukup (C) karena sebagian siswa hanya ribut dan tidak mencatat data hasil temuan. Selanjutnya pada langkah ketiga yaitu siswa berkelompok mendiskusikan hasil temuan dan memaknai data hasil temuan, pada langkah ini dilakukan dengan kategori cukup (C) karena sebagian besar siswa tidak terlihat berdiskusi dengan teman kelompoknya, langkah keempat yaitu siswa secara kolaboratif menyusun laoparan kegiatan, pada langkah ini dilakukan dengan kategori cukup (C) karena siswa kurang berkerjasama dengan teman kelompoknya untuk menyusun laporan hasil kegiiatan. Langkah kelima yaitu perwakilan kelompok menyajikan hasil temuan dan ditanggapi kelompok lain, pada langkah pembelajaran ini dilakukan dengan kategori kurang (K) karena siswa kurang menanggapi perwakilan kelompok yang membacakan hasil diskusinya. Selanjutnya siswa mendengarkan penguatan materi dari guru dilakukan dengan kategori baik (B) karena siswa menyimak dengan baik apa yang disampaikan guru. Dari enam langkah pembelajaran model discovery learning pada aspek siswa, dikategorikan kurang $72 \%$. 


\section{d. Refleksi Siklus I}

Banyak kekurangan yang terjadi dalam proses pembelajaran siklus I, maka peneliti bersama guru wali kelas V SDN 124 Batuasang selaku observer dan marefleksi dan melihat kembali kelemahan- kelemahan baik dari guru maupun dari siswa itu sendiri yang mempengaruhi proses dan hasil belajar dalam proses pembelajran berlangsung pada siklus I.

1. Guru kurang mengawasi siswa pada saat melakukan diskusi kelompok

2. Guru kurang membimbing kelompok untuk menanggapi jawaban atau hasil kerja kelompok lain

3. Tidak semua kelompok aktif dalam mengerjakan tugas kelompok

4. Tidak semua siswa aktif dalam belajar

Berdasarkan kekurangan dan kelemahan dalam proses pembelajaran pada siklus I baik dari guru maupun siswa dalam keberlangsungan proses pembelajaran, maka tindakan yang dilakukan oleh peneliti untuk memperbaiki kesalahan atau kelemahankelemahan dalam pelaksanaan siklus I adalah sebagai berikut:

1. Peneliti harus mengawasi siswa pada saat melakukan diskusi

2. Peneliti haru memberi bimbingan kepada siswa untuk berani mempresentasikan dan menanggapi hasil temuan yang telah dilakukan

3. Memberi arahan atau penjelasan kepada siswa agar dapat bekerjasama dalam kelompok

4. Melibatkan siswa dalam melakukan percobaan

\section{Paparan Data Siklus II}

Rencana pelaksanaan siklus II ini merupakan upaya untuk menyempurnakan tindakan siklus I dan lebih meningkatkan hasil belajar siswa kelas V SDN 124 Batuasang Kecamatan Herlang Kabupaten Bulukumba. Pada penelitian ini peneliti bertidak sebagai guru dalam proses pembelajaran, dan guru kelas $\mathrm{V}$ bertindak sebagai pengamat. Rancangan tindakan siklus II sama dengan rancangan tindakan siklus I yaitu dirancang dalam dua kali pertemuan, proses pembelajaran tiap pertemuan disusun berdasarkan langkah- langkah dalam model pembelajan discovery learning.

\section{a. Rancangan Siklus II}

Rancangan pelaksanaan tindakan siklus II dilaksanakan dalam dua kali pertemuan yang dilaksanakan pada hari rabu 9 mei 2018 pada pertemuan I dan hari sabtu 12 mei 2018 pada pertemuan II. Perencanaan pertemuan I dengan materi sifat- sifat cahaya pada benda bening dan benda gelap. Sedangkan pertemuan II dengan materi sifatsifat cahaya pada cermin datar, cembung dan cekung. Perencanaan pembelajaran disusun oleh peneliti dan guru kelas $\mathrm{V}$ dengan mengacu pada langkah- langkah model pembelajaran Discovery Learning. Kegiata yang dilakukan pada tindakan siklus II meliputi perencanaan, pelaksanaan, observasi, dan refleksi.

\section{b. Pelaksanaan Siklus II}

Pelaksanaan siklus II dilaksanakan dalam 2 tindakan $(2 \mathrm{x}$ pertemuan) dengan alokasi waktu $3 \times 35$ menit tiap pertemuan mulai pukul 09.30- 10.45 yang dilaksanakan pada hari rabu 9 mei 2018 dan sabtu 12 mei 2018 sesuai dengan rencana yang telah disusun pada RPP pertemuan I siklus II (lampiran 20 halaman 103) dan RPP pertemuan II siklus II (lampiran 27 halaman 116). Materi siklus II yaitu sifat- sifat cahaya dengan mengadakan tes akhir siklus II pada pertemuan II yang diikuti oleh seluruh siswa kelas V SDN 124 Batuasang Kacamatan Herlang Kabupaten Bulukumba yang berjumlah 14 orang.

\section{1) Pertemuan I Siklus II}

Pada pertemuan I siklus II dilaksanakan pada hari rabu tanggal 9 mei 2018 dengan materi sifat- sifat cahaya benda bening dan gelap, terdiri dari tiga kegiatan yakni kegiatan awal, kegiatan inti dan kegiatan penutup. Alokasi waktu pada pertemuan ini adalah $3 \times 35$ menit, proses pemebelajaran dilaksanakan pada pukul 09.30-10.45 WITA.

a) Kegiatan Awal

Pada kegiatan awal berlangsung selama \pm 15 menit yaitu guru mengucapkan salam dan siswa menjawab salam, kemudian mengecek kesiapan belajar siswa dan melanjutkan doa bersama. Selanjutnya guru mengecek kehairan siswa yang berjumlah 14 orang siswa yang terdiri dari 10 laki- laki dan 4 perempuan, setelah mengecek kehadiran diketahui bahwa siswa yang hadir pada pertemuan I siklus II hadir semua. Kemudian dilanjutkan apersepsi dengan cara bertanya hal- hal yang berkaitan dengan materi yang akan dipelajari. Setelah melakukan apersepsi, guru menyampaikan tujuan dal langkahlangkah pembelajaran, kemudian siswa menyimak tujuan dan langkah- langkah pembelajaran tersebut.

b) Kegiatan Inti 
Pada kegiatan ini berlangsung selama \pm 80 menit. Dengan mengawali kegiatan inti, guru membentuk siswa dalam kelompok dikarenakan langkah- langkah model pembelajaran discovery learning ada kegiatan diskusi kelompok Untuk memudahkan guru dalam membimbing setiap kelompok maka guru membagi siswa kedalam 3 kelompok, dua kelompok beranggotankan 5 orang dan satu kelompok beranggotakan 4 orang hal ini dikarenakan jumlah siswa kelas V memiliki 14 orang siswa. Setalah semua siswa berada pada kelompok masing- masing, maka guru menjelaskan langkah- langkah yang akan dilakukan dalam kegiatan percobaan tentang gaya magnet.

a. Melakukan eksplorasi, percobaan

Guru membagikan lembar kerja siswa (LKS), pada LKS ini memuat langkahlangkah kegiatan yang akan dilakukan siswa yaitu percobaan tentang sifat- sifat cahaya pada benda bening dan gelap, adapun langkahlangkah kegiatan yaitu (1) meminta siswa menyalakan lampu senter kemudian mengarahkan cahaya yang dihasilkan ke gelas yang berisi air jernih, (2) melakukan pengamatan terhadap arah berkas sinar yang diarahkan kepada benda- benda yang telah disiapkan, (3) meminta siswa melakukan langkah nomor satu dengan mengamati gelas yang berisi air jernih secara bergantian dengan karton, plastik, kaca, dan buku tebal.

b. Mencatat hasil

Guru meminta siswa untuk mencatat seluruh data hasil percobaan yang sudah dilakukan dan berdiskusi dengan teman kelompoknya untuk menjawab pertanyaan yang ada pada LKS dimana pertanyaan disesuaikan dengan percobaan yang telah dilakukan

c. Mendiskusikan

Siswa diminta untuk mendiskusikan hasil kegiatan yang telah dilakukan secara berkelompok.

d. Menyusun laporan kegiatan

Siswa diminta untuk membuat laporan secara berkelompok tentang hasil kegiatan yang telah dilakukan kemudian dipresentasikan oleh ketua disetiap kelompok. e. Presentasi

Ketua kelompok mempresentasikan hasil kerja kelompok dan membacakan di depan kelas dan kelompok lain menanggapi hasil kerja kelompok yang dibacakan.

f. Penjelasan Materi

Guru memberikan penguatan materi atau menjelaskan lebih lanjut yang sudah dipelajari tentang sifat- sifat cahaya pada benda bening dan gelap.

c) Kegiatan Penutup

Kegiatan penutup ini berlangsung selama \pm 10 menit, yang pertama dilakukan yaitu guru bersama siswa menyimpulkan materi pelajaran, kemudian guru memberikan motivasi yang membengun kepada siswa dan menyampaikan pesan- pesan moral kepada siswa, seperti jangan lupa mengulangi pelajarannya di rumah, rajin membantu oranng tua dan shalat lima waktu. Kemudian yang terakhir mengucapkan salam penutup untuk mengakhiri pembelajaran.

\section{2) Pertemuan II Siklus II}

Pertemuan II dilaksanakan pada hari sabtu 12 mei 2018 dengan materi sifat- sifat cahaya pada cermin datar, cembung dan cekung terdiri dari tiga kegiatan yakni kegiatan awal, kegiatan inti dan kegiatan penutup. Alokasi waktu pada pertemuan ini adalah $3 \mathrm{x}$ 35 menit, proses pembelajaran dilaksanakan pada pukul 09.30- 10.45 WITA

a) Kegiatan Awal

Pada kegiatan awal berlangsung selama \pm 15 menit yaitu guru mengucapkan salam dan siswa menjawab salam, kemudian mengecek kesiapan belajar siswa dan melanjutkan doa bersama. Selanjutnya guru mengecek kehairan siswa yang berjumlah 14 orang siswa yang terdiri dari 10 laki- laki dan 4 perempuan, setelah mengecek kehadiran diketahui bahwa siswa yang hadir pada pertemuan I siklus II hadir semua. Kemudian dilanjutkan apersepsi dengan cara bertanya hal- hal yang berkaitan dengan materi yang akan dipelajari. Setelah melakukan apersepsi menghubungkan materi sebelumnya dengan materi yang akan dipelajari, guru menyampaikan tujuan dal langkah- langkah pembelajaran, kemudian siswa menyimak tujuan dan langkah- langkah pembelajaran tersebut.

b) Kegiatan Inti

Pada kegiatan inti berlangsung selama \pm 70 menit dengan materi sifat- sifat cahaya pada cermin datar, cembung dan cekung melalui percobaan.

a. Melakukan eksplorasi, percobaan

Guru membagikan lembar kerja siswa (LKS), pada LKS ini memuat langkahlangkah kegiatan yang akan dilakukan siswa yaitu percobaan tentang sifat- sifat cahaya pada cermin datar, cembung dan cekkung, adapun langkah- langkah kegiatan yaitu (1) meminta siswa berkaca pada cermin datar 
kemudian mengamati bayangan yang terbentuk, (2) meminta siswa berkaca pada bagian sendok yang mengkilap (cermin cembung) kemudian mengamati bayangan yang terbentuk, (3) meminta siswa berkaca pada bagian sendok yang mengkilap (cermin cekung) kemudian mengamati bayangan yang terbentu.

b. Mencatat hasil

Guru meminta siswa untuk mencatat seluruh data hasil percobaan yang sudah dilakukan dan berdiskusi dengan teman kelompoknya untuk menjawab pertanyaan yang ada pada LKS dimana pertanyaan disesuaikan dengan percobaan yang telah dilakukan

\section{c. Mendiskusikan}

Siswa diminta untuk mendiskusikan hasil kegiatan yang telah dilakukan secara berkelompok.

d. Menyusun laporan kegiatan

Siswa diminta untuk membuat laporan secara berkelompok tentang hasil kegiatan yang telah dilakukan kemudian dipresentasikan oleh ketua disetiap kelompok.

e. Presentasi

Ketua kelompok mempresentasikan hasil kerja kelompok dan membacakan di depan kelas dan kelompok lain menanggapi hasil kerja kelompok yang dibacakan.

f. Penjelasan Materi

Guru memberikan penguatan materi atau menjelaskan lebih lanjut yang sudah dipelajari tentang sifat- sifat cahaya pada cermin datar, cembung dan cekung.

c) Kegiatan Penutup

Kegiatan penutup ini berlangsung selama \pm 20 menit yaitu guru menyimpulkan materi pelajaran, kemudian memberikan tes siklus II kepada masing- masing siswa, selanjutnya memberikan motivasi kepada siswa dan menyampaikan pesan- pesan moral agar siswa tidak lupa mengulangi pelajaran di rumah, rajin membantu orang tua dan melaksanakan shalat lima waktu. Kemudian yang terakhir mengucapkan salam penutup untuk mengakhiri pembelajaran pertemuan II siklus II.

Setelah pelaksanaan pertemuan II siklus II, peneliti yang sekaligus bertindak sebagai guru memerikasa tes siklus II siswa. Berdasarkan hasil pemriksaan tes siklus II tersebut, nilai rata- rata yang diperoleh siswa mencapai $85.71 \%$.

\section{c. Hasil Observasi Siklus II}

Fokus pengamatan pada siklus II ini tidak jauh berbeda dengan siklus I yaitu aktivitas guru dan siswa selama proses pembelajaran yang disesuaikan kegiatan pada RPP yang terdiri dari tiga kegiatan yaitu kegiatan awal, kegiatan inti dan kegiatan penutup. Hasil observasi selama kegiatan pembelajaran siklus II adalah sebagai berikut:

\section{1) Pertemuan I Siklus II}

a) Aspek guru

Kegiatan inti diawali dengan guru meminta siswa melakukan kegiatan eksplorasi, pencarian, dan penelusuran untuk mendapatkan informasi dilakukan dengan kategori baik (B), karena guru memberikan arahan dan menjelaskan kegiatan eksplorasi apa yang akan dilakukan, kemudian pada langkah kedua guru meminta siswa mencatat seluruh data hasil percobaan dilakukan dengan kategori baik (B) karena guru membimbing siswa dalam mencatat seluruh data hasil percobaan, kemudian pada langkah ketiga guru meminta siswa mendiskusikan hasil temuan dan memaknai data hasil percobaan secara berkelompok pada langkah ini dilakukan dengan kategori cukup (C) karena guru kurang mengawasi jalannya diskusi kelompok sehingga diskusi kurang maksimal, selanjutnya pada langkah keempat yaitu guru meminta siswa secara kolaboratif menyusun laporan kegiatan tentang percobaan yang telah dilakukan pada langkah ini dilakukan dengan kategori cukup (C) karena guru kurang membimbing kelompok dalam menyusun laporan kegiatan. Langkah selanjutnya yaitu guru meminta perwakilan kelompok menyajikan hasil temuan dan di tanggapi oleh kelompok lain, pada langkah pembelajaran ini dilakukan dengan kategori cukup (C) karena guru meminta perwakilan kelompok untuk mempresentasikan hasil diskusi dan hanya beberapa kelompok menanggapi. Selanjutnya Guru memberikan penguatan materi atau memberikan pelajaran dilakukan dengan kategori baik (B) karena guru menyampaikan materi dengan baik dan jelas. Dari enam langkah pembelajaran model discovery learning pada aspek guru, dikategorikan baik $83 \%$.

b) Aspek Siswa

Kegiatan inti diawali dengan siswa melakukan kegiatan ekplorasi, pencarian, penelusuran untuk mendapatkan informasi dilakukan dengan kategori baik (B) karena siswa terlihat melakukan kegiatan ekplorasi, pencarian untuk mendapatkan informasi, selanjutnya siswa mencatat seluruh kegiatan yang dilakukan pada langkah ini dilakukan dengan kategori cukup (C) karena sebagian siswa hanya ribut dan tidak mencatat data hasil 
temuan. Selanjutnya pada langkah ketiga yaitu siswa berkelompok mendiskusikan hasil temuan dan memaknai data hasil temuan, pada langkah ini dilakukan dengan kategori cukup (C) karena siswa belum terlihat berdiskusi dengan teman kelompoknya, langkah keempat yaitu siswa secara kolaboratif menyusun laoparan kegiatan, pada langkah ini dilakukan dengan kategori cukup (C) karena hanya ketua kelompok yang terlihat menyusun laporan hasil kegiatan. Langkah kelima yaitu perwakilan kelompok menyajikan hasil temuan dan ditanggapi kelompok lain, pada langkah pembelajaran ini dilakukan dengan kategori cukup (C) karena sebagian siswa kurang menanggapi perwakilan kelompok yang membacakan hasil diskusinya. Selanjutnya siswa mendengarkan penguatan materi dari guru dilakukan dengan kategori baik (B) karena siswa menyimak dengan baik apa yang disampaikan guru. Dari enam langkah pembelajaran model discovery learning pada aspek siswa, dikategorikan cukup 77\%.

\section{2) Pertemuan II Siklus II}

a) Aspek Guru

Kegiatan inti diawali dengan guru meminta siswa melakukan kegiatan eksplorasi, pencarian, dan penelusuran untuk mendapatkan informasi dilakukan dengan kategori baik (B), karena guru memberikan arahan dan menjelaskan kegiatan eksplorasi apa yang akan dilakukan, kemudian pada langkah kedua guru meminta siswa mencatat seluruh data hasil percobaan dilakukan dengan kategori baik (B) karena guru membimbing siswa dalam mencatat seluruh data hasil percobaan, kemudian pada langkah ketiga guru meminta siswa mendiskusikan hasil temuan dan memaknai data hasil percobaan secara berkelompok pada langkah ini dilakukan dengan kategori baik (B) karena guru mengawasi jalannya diskusi kelompok sehingga diskusi kurang maksimal, selanjutnya pada langkah keempat yaitu guru meminta siswa secara kolaboratif menyusun laporan kegiatan tentang percobaan yang telah dilakukan pada langkah ini dilakukan dengan kategori baik (B) karena guru membimbing kelompok dalam menyusun laporan kegiatan. Langkah selanjutnya yaitu guru meminta perwakilan kelompok menyajikan hasil temuan dan di tanggapi oleh kelompok lain, pada langkah pembelajaran ini dilakukan dengan kategori cukup (C) karena guru meminta perwakilan kelompok untuk mempresentasikan hasil diskusi dan hanya beberapa kelompok menanggapi. Selanjutnya Guru memberikan penguatan materi atau memberikan pelajaran dilakukan dengan kategori baik (B) karena guru menyampaikan materi dengan baik dan jelas. Dari enam langkah pembelajaran model discovery learning pada aspek guru, dikategorikan baik $94 \%$.

b) Aspek Siswa

Kegiatan inti diawali dengan siswa melakukan kegiatan ekplorasi, pencarian, penelusuran untuk mendapatkan informasi dilakukan dengan kategori baik (B) karena siswa terlihat melakukan kegiatan ekplorasi, pencarian untuk mendapatkan informasi, selanjutnya siswa mencatat seluruh kegiatan yang dilakukan pada langkah ini dilakukan dengan kategori baik (B) karena siswa mencatat data hasil temuan yang telah dilakukan. Selanjutnya pada langkah ketiga yaitu siswa berkelompok mendiskusikan hasil temuan dan memaknai data hasil temuan, pada langkah ini dilakukan dengan kategori cukup (C) karena siswa belum terlihat berdiskusi dengan teman kelompoknya, langkah keempat yaitu siswa secara kolaboratif menyusun laoparan kegiatan, pada langkah ini dilakukan dengan kategori baik (B) karena siswa secara kolaboratif menyusun laporan hasil kegiatan. Langkah kelima yaitu perwakilan kelompok menyajikan hasil temuan dan ditanggapi kelompok lain, pada langkah pembelajaran ini dilakukan dengan kategori cukup (C) karena sebagian siswa kurang menanggapi perwakilan kelompok yang membacakan hasil diskusinya. Selanjutnya siswa mendengarkan penguatan materi dari guru dilakukan dengan kategori baik (B) karena siswa menyimak dengan baik apa yang disampaikan guru. Dari enam langkah pembelajaran model discovery Learning pada aspek siswa, dikategorikan baik $83 \%$.

\section{d. Refleksi Siklus II}

Bedasarkan hasil observasi dan tes hasil belajar pada siklus II yang memfokuskan pada perbaikan dalam peningkatan proses dan hasil belajar yang dilakukan baik oleh guru maupun siswa dalam proses pembelajaran dengan menggunakan model discovery learning mengalami peningkatan dalam kategor baik. Peningkatan hasil tes siklus II tidak terlepas pada perbaikan- perbaikan dari sikulus I diantaranya:

1. Peneliti sudah mengawasi siswa pada saat melakukan diskusi

2. Dengan memberikan pengertian kepada siswa agar siswa dapat menerima kekurangan teman 
3. Siswa lebih konsentrasi dalam proses pembelajaran

4. Dalam proses pembelajaran sudah melibatkan seluruh siswa untuk melakukan percobaan

Hal ini terbukti dari hasil tes siklus II menunjukkan bahwa dari 14 orang siswa memperoleh skor rata- rata kelas yaitu $85.71 \%$. Skor tertinggi 100 dan skor terendah 70 dengan skor ideal 100.

\section{B. Pembahasan}

Hasil belajar siswa yang diperoleh setelah dilaksanakan siklus I dalam pembelajaran IPA dengan materi gaya magnet, gaya gravitasi dan gaya gesek dengan menggunakan model pembelajaran discovery learning, skor rata-rata yang diperoleh adalah $68.57 \%$ dengan nilai tertinggi 80 dan yang terendah 50 dari skor idela 100 , dan yang tuntas hasil belajarnya 6 orang siswa dan yang tidak tuntas hasil belajarnya 8 orang siswa. Ini disebabkan karena siswa kurang berparsipasi aktif dalam pembelajaran, siswa kurang berkonsentrasi pada saat pembelajaran berlangsung, siswa kurang terampil dan menemukan sendiri. Oleh karena itu setelah pembelajaran selesai guru lebih banyak memberikan arahan dan bimbingan dalam menyelesaikan tugas yang diberikan.

Pada siklus II pelaksanaan pembelajaran berjalan dengan baik karena siswa dapat berpartisipsasi aktif dalam mengikuti pembelajaran sehingga proses pembelajaran berlajan secara optimal. Dilihat dari proses dan hasil belajar tes akhir yang telah dicapai, yaitu skor nilai rata-rata tes akhir menunjukkan peningkatan pada siklus I yaitu $68.57 \%$, sedangkan siklus II nilai rata-rata skor adalah $85.71 \%$ dengan nilai tertinggi 100 dan nilai terendah 70 . Siswa yang tuntas hasil belajarnya 12 orang dan siswa tidak tuntas hasil belajarnya 2 orang. Jelaslah bahwa dengan menerapkan model pembelajaran discovery learning dapat meningkatkan hasil belajar siswa dalam pembelajaran IPA khususnya pada materi sifat- sifat cahaya. Hal ini sejalan dengan pendapat Hosnan, (2013: 282) mengartikan pembelajaran discovery learning sebagai berikut: Discovery Learning adalah suatu model untuk mengembangkan cara belajar siswa aktif dengan menemukan sendiri, menyelidiki sendiri, maka hasil yang akan diperoleh akan setia dan tahan lama dalam ingatan, tidak akan mudah dilupakan siswa.
Dengan belajar penemuan, siswa juga belajar berpikir analisis dan mencoba memecahkan masalah yang dihadapi sehingga pembelajaran yang dilakukan dengan menerapkan model pembelajaran discovery learning untuk meningkatkan hasil belajar siswa pada mata pelajaran IPA di SDN 124 Batuasang Kecamatan Herlang Kabupaten Bulukumba. Oleh karena itu, model pembelajaran discovery learning memungkinkan untuk dijadikan sebagai salah satu model pembelajaran dalam meningkatkan hasil belajar siswa dalam pelajaran IPA khususnya di SD.

\section{KESIMPULAN \& SARAN}

Berdasarkan hasil penelitian yang diperoleh, maka dapat disimpulkan bahwa: Aktivitas mengajar guru dan aktivitas belajar siswa dalam pembelajaran IPA dengan menerapkan model pembelajaran Discovery Learning terjadi peningkatan pada aktivitas guru dan hasil belajar siswa. Peningkatan dapat dilihat dari setiap siklus. Pada siklus I aktivitas mengajar guru dan siswa berada pada kategori cukup mengalami peningkatan di siklus II menjadi baik.Hasil belajar siswa pada siklus I belum berhasil mencapai ketuntasan klasikal siswa yang telah ditentukan dan berada padaka tegori cukup, sedangkan pada siklus II hasil belajar siswa sudah meningkat, hal itu dilihat dari nilai rata- rata yang mengalami peningkatan dan berada pada kategori baik, penerapan Model Pembelajaran discovery learning dalam mata pelajaran IPA dapat meningkatkan hasil belajar siswa kelas V SDN 124 Baruasang Kecamatan Herlang Kabupaten Bulukumba.

Kepala sekolah hendaknya selalu memberikan pembinaan dan pengawasan terhadap pelaksanaan tugas mengajar guru, di antaranya dalam penggunaan model pembelajaran. Guru kelas V, agar dapat menggunakan model pembelajaran discovery learning dalam proses belajar mengajar pada mata pelajaran IPA khususnya materi sifatsifat cahaya, karena model ini dapat memotivasi siswa untuk belajara, serta dapat membantu siswa memahami materi pelajaran. Senantiasa memberikan pujian atau penghargaan kepada siswa yang telah memberikan jawaban benar ataupun pendapat, agar siswa lebih termotivasi untuk belajar. Dan sebaiknya lebih membimbing siswa yang kurang aktif dalam proses pembelajaran. Bagi peneliti yang ingin melakukan penelitian yang sama hendaknya hasil penelitian ini dapat 
dijadikan sebagai panduan, dimana kekurangan- kekurangan dan kelebihankelebihan yang terdapat pada penelitian ini dapat dijadikan sebagai bahan refleksi demi penyempurnaan penelitian di masa- masa berikutnya.

\section{DAFTAR PUSTAKA}

Arikunto, Suharsimi, dkk. 2017. Penelitian Tindakan Kelas. Jakarta: Bumi Aksara.

Kunandar. 2008. Penelitian Tindakan Kelas. Jakarta: PT Raja Grafindo Persada.

Purwanto. 2016. Evaluasi Hasil Belajar. Yogyakarta: Pustaka Pelajar.

Sanjaya, Wina. 2013. Penelitian Tindakan Kelas. Jakarta: PT Fajar Interpratama Mandiri.

Silbermen, L Melvin. 2014. Actif Learning. Bandung: Nuasa Cendekia.

Sugiyono. 2016. Model Penelitian Kuantitatif, Kualitatif, dan R\&D. Bandung: Alfabet. 